\title{
UPAYA MENINGKATKAN AKTIVITAS DAN HASIL BELAJAR MATEMATIKA POKOK BAHASAN TRIGONOMETRI DENGAN MENGGUNAKAN MODEL PEMBELAJARAN KOOPERATIF TIPE NHT SISWA KELAS XII IPA 4 SMAN 3 KOTABUMI TAHUN PELAJARAN 2018-2019
}

\author{
Anariyana \\ SMA Negeri 3 Kotabumi
}

\begin{abstract}
The main problem faced at SMA Negeri 3 Kotabumi is the low activity and student learning outcomes due to less varied learning methods. Therefore, this study aims to improve the activities and learning outcomes of Mathematics using NHT type cooperative learning models on Trigonometry material for SMA Negeri 3 Kotabumi students. This research was conducted to 34 students of class XII Science 4, in this study tested the use of NHT type cooperative learning models on Trigonometry material to determine their effects on student learning outcomes. The study was divided into 3 cycles by collecting data using cognitive tests and student attitude questionnaires obtained from each cycle, the results were analyzed whether there was an increase in each cycle. The results of this study indicate that there is an increase in learning outcomes $20 \%$ from cycle I to cycle II and an increase of $27 \%$ from cycle II to cycle III, while student activity has increased from cycle I by 78, to 81 in cycle II and 83 in cycle III, activity asessment indicators in the form of discipline, cooperation, courtesy and tolerance in learning
\end{abstract}

Keyword: Cooperative type NHT, Mathematics learning outcome.

\section{PENDAHULUAN}

Pendidikan memegang peranan penting dalam proses peningkatan kualitas sumber daya manusia. Untuk dapat memperoleh sumber daya manusia yang berkualitas, dibutuhkan juga pendidikan yang berkualitas. Salah satu tujuan pendidikan adalah untuk memberikan bekal kecakapan hidup kepada seseorang manusia yang nantinya akan sangat berguna dalam kehidupannya. Kecakapan hidup yang dimaksud adalah kecakapan personal, kecakapan sosial, kecakapan intelektual, kecakapan akademis, dan kecakapan vokasional.

Salah satu masalah yang dihadapi dalam dunia pendidikan di Indonesia adalah rendahnya pencapaian hasil belajar siswa. Salah satu penyebab rendahnya pencapaian hasil belajar adalah pengajaran masih dipandang sebagai transfer pengetahuan belum sebagai upaya membangun pengetahuan, keterampilan proses, dan sikap sains. Selain itu siswa banyak mengalami kesulitan-kesulitan yang berasal dari diri siswa itu sendiri yang disebut kesulitan internal dan kesulitan yang berasal dari luar diri siswa yang 
disebut kesulitan eksternal. Kesulitan internal itu berupa rendahnya kemampuan kognitif, minat, bakat, dan motivasi siswa. Kesulitan eksternal, berupa kuranya fasilitas, tidak tepatnya strategi belajar yang diterapkan guru.

Untuk menjawab persoalan-persoalan tersebut, diupayakan adanya paradigma baru dalam pembelajaran di kelas yaitu melalui Model Pembelajaran Kooperatif Tipe NHT (Numbered Heads Together) agar permasalahan tersebut tidak terus berlanjut, maka upaya peningkatan hasil belajar matematika harus segera dilakukan. Salah satu hal yang dapat dilakukan untuk meningkatkan kualitas tersebut adalah "Model Pembelajaran Kooperatif Tipe NHT (Numbered Heads Together) yang mengajak peserta didik menyusun dan memamerkan hasil karya dengan kemampuannya, hal ini dicirikan dengan kerja sama antara peserta didik dalam suatu kelompok kecil. Materi pelajaran Matematika kelas XII tentang Trigonometri merupakan materi yang cukup kompleks. Dalam mempelajarinya diperlukan pemahaman rumus dalam mengaplikasikannya dalam soal. Rata-rata nilai Matematika siswa kelas XII SMAN 3 Kotabumi pada tahun ajaran 2017-2018 khususnya bab Trigonometri yaitu 50. Nilai tersebut masih di bawah nilai KKM bab tersebut, yaitu sebesar 75. Hal ini yang melatarbelakangi peneliti untuk melakukan penelitian dengan judul "Upaya Meningkatkan Aktivitas dan Hasil Belajar Matematika Pokok Bahasan Trigonometri dengan Menggunakan Model Pembelajaran Kooperatif Tipe NHT Siswa Kelas XII IPA 4 SMAN 3 Kotabumi Tahun Pelajaran 2018-2019 “. Dari permasalahan tersebut diidentifikasi permasalahan pada penelitian ini adalah:

Apakah ada peningkatan aktivitas dan hasil belajar matematika pokok bahasan Trigonometri dengan menggunakan model pembelajaran Kooperatif tipe NHT siswa kelas XII IPA 4 SMAN 3 Kotabumi Tahun Pelajaran 2018-2019? Tujuan penelitian ini adalah Meningkatkan aktivitas dan hasil belajar Matematika pokok bahasan Trigonometri dengan menggunakan model pembelajaran Kooperatif tipe NHT siswa kelas XII IPA 4 SMAN 3 Kotabumi Tahun Pelajaran 2018-2019.

Belajar merupakan suatu proses atau kegiatan kompleks yang terjadi pada setiap orang dan berlangsung seumur hidup. Arikunto (2005:19) mengartikan belajar sebagai suatu proses yang terjadi karena adanya usaha untuk mengadakan perubahan terhadap diri manusia yang melakukan dengan maksud memperoleh perubahan dalam dirinya baik berupa pengetahuan, keterampilan serta sikap

Menurut Suryabrata (2006:297), hasil belajar dapat didefinisikan sebagai berikut: “nilai merupakan perumusan terakhir yang 
dapat diberikan oleh guru mengenai kemajuan/prestasi belajar siswa selama masa tertentu".

Dalam taksonomi Bloom tujuan pembelajaran dapat diklasifikasikan ke dalam tiga ranah (domain), yaitu:

a. Domain kognitif; berkenaan dengan kemampuan dan kecakapan-kecakapan intelektual berpikir;

b. Domain afektif; berkenaan dengan sikap, kemampuan dan penguasaan segi-segi emosional, yaitu perasaan, sikap, dan nilai.

c. Domain psikomotorik; berkenaan dengan suatu keterampilan-keterampilan atau gerakan-gerakan fisik. (Rusman, 125:2012).

Jadi, hasil belajar adalah hasil usaha siswa selama masa tertentu melakukan kegiatan.

Numbered Heads Together adalah model pembelajaran dengan cara setiap siswa diberi nomor dan dibuat suatu kelompok, kemudian secara acak guru memanggil nomor dari siswa. Slavin (2005: 256) memaparkan NHT pada dasarnya adalah sebuah group discussion, pembelokannya yaitu hanya pada satu siswa yang akan menjadi wakil kelompok tersebut. Tetapi sebelumnya tidak diberi tahu siapa yang menjadi wakil kelompok tersebut. Penerapan model NHT memastikan keterlibatan total dari semua siswa. Suprijono (2009:92) memaparkan langkah-langkah pembelajaran menggunakan numbered heads together yakni:

1. Numbering, yaitu guru membagi kelas menjadi kelompok-kelompok kecil.

2. Guru mengajukan beberapa pertanyaan yang harus dijawab oleh tiap-tiap kelompok.

3. Kelompok berdiskusi menemukan jawaban. Pada kesempatan ini tiap-tiap kelompok berdiskusi memikirkan jawaban atas pertanyaan dari guru. Menyatukan kepala "heads together". Guru memanggil peserta didik yang memiliki nomor yang sama tiap tiap kelompok. Mereka diberi kesempatan memberi jawaban atas pertanyaan yang telah diterimanya dari guru. Berdasarkan jawaban itu guru dapat mengembangkan diskusi lebih mendalam, sehingga peserta didik dapat menemukan jawaban pertanyaan itu sebagai pengetahuan yang utuh.

\section{METODE PENELITIAN}

Subyek penelitian ini adalah peserta didik kelas XII IPA 4 SMAN 3 Kotabumi dengan jumlah peserta didik 34 orang Penelitian tindakan kelas ini dilaksanakan pada semester ganjil tahun pelajaran 2018/2019 yang dilaksanakan pada bulan Oktober 2018. Penelitian tindakan ini dilakukan di SMAN 3 Kotabumi, Lampung Utara. Kegiatan dirancang dengan penelitian tindakan kelas, kegiatan diterapkan dalam upaya meningkatkan hasil 
belajar Matematika peserta didik. Tahapan langkah disusun dalam siklus penelitian. Setiap siklus terdiri atas perencanaan, pelaksanaan, pengamatan, dan refleksi. Instrumen penelitian yang digunakan oleh peneliti sebagai berikut:

\section{Angket Kemampuan Afektif}

Lembar Angket kemampuan afektif disusun untuk mengetahui sikap peserta didik dalam proses belajar berlangsung menggunakan model pembelajarn kooperatif tipe NHT.

2. Tes Kemampuan Kognitif

Tes dilaksanakan pada akhir kegiatan belajar mengajar. Hasil tes ini digunakan untuk mengukur hasil belajar matematika dan tingkat ketuntasan belajar.

Dalam menganalisis data digunakan rumus sebagai berikut:

a. Data hasil angket meliputi penilaian afektif. Dalam penilaian hasil belajar afektif digunakan skala dengan rentang dari 5 sampai 1. Dengan demikian, jika dari penelitian ada 5 aspek yang harus diamati maka skor maksimum adalah aspek dinilai dikalikan 5. Data hasil angket penilaian afektif dihitung dengan menggunakan rumus sebagai berikut:

$N I L A I=\frac{\Sigma \text { skor penjumlahan }}{\Sigma \text { tertinggi }} \times 100 \%$
Dengan penilaian

1) Nilai $85 \%$ - $100 \%$ sangat baik

2) Nilai $69 \%$ - $84 \%$ baik

3) Nilai $53 \%$ - $68 \%$ cukup

4) Nilai 37\% - 52\% kurang

5) Nilai kurang $36 \%$ gagal

b. Hasil belajar siswa

Indikator yang digunakan untuk mengukur hasil belajar siswa:

1) Aspek kognitif Indikator untuk aspek kognitif, menggunakan standar KKM yang telah ditentukan sekolah yaitu 75 . Hasil belajar kognitif peserta didik dihitung sebagai berikut:

Nilai $=\frac{\text { Sjawaban benar }}{\sum \text { soal }} \times 100 \%$

Rata-rata hasil belajar peserta didik dihitung sebagai berikut:

$\bar{X}=\frac{\Sigma X}{N}$

Keterangan:

$\bar{X}=$ nilai rata-rata nilai siswa

$\Sigma X=$ jumlah seluruh nilai

$\mathrm{N}=$ jumlah peserta didik yang

mengikuti tes

Secara klasikal peserta didik dikatakan tuntas dalam satu pokok bahasan jika kompetensi minimalnya mencapai $75 \%$. Berdasarkan hasil pengamatan, tes tiap siklus apabila masih dirasakan gagal, 
peneliti mencari dugaan penyebab kekurangan sekaligus alternatif solusi untuk dirancang pada tindakan berikutnya.

\section{HASIL DAN PEMBAHASAN}

\section{Siklus I}

Penelitian tindakan kelas ini dilaksanakan secara bertahap yaitu dengan tiga tahapan tiga siklus. Tiap-tiap siklus terdiri atas perencanaan, pelaksanaan, pengamatan, dan refleksi. Dalam pelaksanaan siklus I pembelajaran dilakukan dengan model pembelajaran kooperatif tipe NHT. Sikap siswa pada pembelajaran kooperatif tipe NHT sangat membantu siswa dalam memahami trigonometri pada tiap siklus. Pada siklus I guru memberikan materi sesuai dengan rencana program pengajaran (RPP) yang telah dibuat sebelumnya. Pada tahap pendahuluan/apersepsi guru menjelaskan rumus perkalian sinus cosinus selanjutnya siswa berdiskusi tentang pemecahan soal-soal perkalian sinus cosinus. Setelah siswa memahami hasil diskusi, siswa diberi kesempatan unuk menjelaskan hasil diskusi di depan kelas sesuai nomor yang dimilikinya

Berdasarkan hasil tes formatif siklus I diperoleh ketuntasan belajar sebesar $24 \%$ dan rata-rata aktifitas belajar untuk indikator disiplin, kerjasama, santun dan toleran sebesar 78. Oleh karena itu, untuk memperoleh aktifitas dan hasil belajar yang lebih baik perlu dilanjutkan dengan tindakan perbailan pada siklus II.

\section{Siklus II}

Siklus II dilakukan berdasarkan hasil refleksi siklus I, pada siklus kedua guru menjelaskan rumus penjumlahan sinus cosinus. Selanjutnya siswa berdiskusi tentang penyelesaian soal-soal penjumlahan sinus cosinus. Pada siklus ini tanpa dibimbing oleh guru, siswa telah memahami langkah pembelajaran sehingga mempersiapkan dirinya untuk presentasi didepan kelas dengan melakukan diskusi sebaik mungkin. Keaktifan siswa dapat dilihat pada disiplin dalam diskusi semakin membaik, siswa benar-benar memanfaatkan kegiatan diskusi agar dapat memahami materi. Hasil belajar pada siklus II menunjukkan persentase ketuntasan belajar sebesar $44 \%$ dan aktifitas belajar rata-rata sebesar 81, meningkat lebih baik dari siklus I. Namun demikian masih ada siswa yang belum tuntas belajar sehingga perlu untuk melakukan perbaikan pada siklus III.

\section{Siklus III}

Data yang terkumpul melalui kegiatan pembelajaran siklus III diketahui bahwa aktifitas siswa sudah semakin baik. Siswa yang dinyatakan tuntas pada tes formatif siklus III sebesar $71 \%$.

Peningkatan aktivitas dan hasil belajar pada siklus III terjadi karena guru 
telah berupaya mengelola pembelajaran melalui penggunaan model pembelajaran dengan sungguh - sungguh.

Dari hasil refleksi tersebut disimpulkan bahwa tindakan perbaikan yang peneliti lakukan telah berhasil meski masih ada hal-hal yang perlu diperbaiki. Oleh karena itu, peneliti berupaya menerapkan hal-hal yang positif yang telah dicapai dan memperbaiki hal-hal yang masih kurang seperti; berusaha melibatkan siswa sebanyak mungkin dalam menjawab pertanyaan, dan memberikan perhatian khusus pada anak dengan memberi bimbingan ketika mereka berdiskusi. Dengan demikian perbaikan pembelajaran untuk meningkatkan kemampuan dianggap berhasil sesuai dengan rencana perbaikan sehingga penelitia tindakan kelas kali ini dianggap selesai, dan tidak perlu ada perbaikan pada siklus berikutnya.

Untuk mengetahui gambaran mengenai perkembangan aktivitas dan hasil belajar yang diperoleh selama penelitian dilaksanakan dapat dilihat pada tabel berikut:

Tabel 1

Hasil Belajar Siswa pada Penelitian

\begin{tabular}{|c|c|c|c|c|}
\hline \multirow{2}{*}{ Siklus } & \multicolumn{2}{|c|}{ Jumlah } & \multicolumn{2}{c|}{ Prosentase (\%) } \\
\cline { 2 - 5 } & $\begin{array}{l}\text { Siswa } \\
\text { tuntas }\end{array}$ & $\begin{array}{c}\text { Siswa } \\
\text { tidak } \\
\text { tuntas }\end{array}$ & $\begin{array}{l}\text { Siswa } \\
\text { tuntas }\end{array}$ & $\begin{array}{c}\text { Siswa } \\
\text { tidak } \\
\text { tuntas }\end{array}$ \\
\hline Pertama & 8 & 26 & 24 & 76 \\
\hline Kedua & 15 & 19 & 44 & 56 \\
\hline Ketiga & 24 & 10 & 71 & 29 \\
\hline
\end{tabular}

Tabel 2

Sikap dan Aktivitas Siswa pada Penelitian

\begin{tabular}{|c|c|c|c|}
\hline $\begin{array}{c}\text { Sikap dan } \\
\text { aktivitas siswa }\end{array}$ & $\begin{array}{c}\text { Siklus I } \\
\text { (rata- } \\
\text { rata) }\end{array}$ & $\begin{array}{c}\text { Siklus } \\
\text { II } \\
\text { (rata- } \\
\text { rata) }\end{array}$ & $\begin{array}{c}\text { Siklus } \\
\text { III } \\
\text { (rata- } \\
\text { rata) }\end{array}$ \\
\hline Disiplin & 2,85 & 3 & 3,59 \\
\hline Kerja sama & 2,85 & 2,85 & 3,68 \\
\hline Santun & 2,94 & 3,35 & 3,88 \\
\hline Toleran & 2,82 & 2,94 & 3,82 \\
\hline
\end{tabular}

Rata - Rata kelas Siklus $1=78$

Rata - rata kelas siklus II $=81$

Rata - rata kelas siklus III $=83$

Hasil belajar siswa pada siklus I sebesar $24 \%$ dengan jumlah siswa tuntas sebayak 8 0rang dari 34 siswa, setelah pelaksanaan siklus II mengalami kenaikan persentase ketuntasan sebayak $20 \%$ yaitu $24 \%$ disiklus I menjadi $44 \%$ disiklus II, begitu juga disiklus III persentase ketuntasan naik sebanyak $27 \%$ yaitu dari 44\% disiklus II menjadi 71\% disiklus III.

Aktivitas belajar yang digunakan pada penelitian ini terdiri dari 4 indikator yaitu disiplin, kerjasama, santun, dan toleran. Untuk indikator disiplin pada siklus I sebesar 2,85 menjadi 3 disiklus II dan 3,59 disiklus III. Siswa sudah mulai memahami untuk didiplin memanfaatkan waktu untuk berdiskusi. Untuk indikator kerjasama cenderung tetap dari siklus I ke siklus II, tetapi akhirnya naik di siklus III, yaitu 2,85 untuk siklus I dan siklus II menjadi 3,68 pada siklus III.

Aktivitas siswa untuk indikator santun mengalami kenaikan di tiap 
siklusnya, yaitu 2,94 pada siklus I, menjadi 3,35 di siklus II dan 3,88 disiklus III, siswa mulai terbiasa untuk lebih santun dalam berdiskusi dan ketika menjawab soal. Sama halnya dengan indikator santun, untuk indikator toleran juga mengalami kenaikan yaitu 2,82 di siklus I, menjadi 2,94 di siklus II dan akhirnya 3,82 di siklus III. Siswa semakin toleran membantu teman diskusinya untuk memahami materi pelajaran.

Dari empat indikator penilaian aktifitas diambil rata-rata di tiap siklusnya yaitu pada siklus I sebesar 78 masuk kategori baik, pada siklus II sebesar 81 masuk kategori baik dan pada siklus III rata-rata sebesar 83 juga masuk kategori baik. Oleh karena itu dapat disimpulkan pada penelitian ini terjadi kenaikan aktifitas dan hasil belajar siswa.

\section{SIMPULAN}

Berdasarkan hasil penelitian dan pembahasan, maka PTK dengan judul "Upaya Meningkatkan Aktivitas dan Hasil Belajar Matematika Pokok Bahasan Trigonometri dengan Menggunakan Model
Pembelajaran Kooperatif Tipe NHT Siswa Kelas XII IPA 4 SMAN 3 Kotabumi Tahun Pelajaran 2018-2019” dapat diambil simpulan sebagai berikut:

1. Ada peningkatan ketuntasan belajar pada pembelajaran menggunakan model pembelajaran kooperatif tipe NHT dari siklus $1(24 \%)$ ke siklus 2 (44\%) sampai siklus III(71\%), dan ratarata ketuntasan belajar siswa juga meningkat sebesar $20 \%$ dari siklus I ke siklus II serta sebesar $27 \%$ dari siklus II ke siklus III.

2. Dari hasil angket terlihat bahwa pembelajaran dengan menggunakan model pembelajaran kooperatif tipe NHT dapat meningkatkan aktifitas siswa pada sikap disiplin, kerjasama, santun dan toleran dengan rata-rata aktifitas kelas sebesar 78 pada siklus I dan meningkat pada siklus II sebesar 81 serta menjadi 83 pada siklus III sehingga disimpulkan bahwa model pembelajaran kooperatif tipe NHT dapat meningkatkan aktifitas belajar siswa pada materi Trigonometri. 


\section{DAFTAR PUSTAKA}

Arikunto, Suharsimi. 2008. Penelitian Tindakan Kelas. Jakarta: Bumi Aksara

Dimyati, dkk. 2006. Belajar dan Pembelajaran. Jakarta. Penerbit Rineka Cipta.

Miles M.B dan Huberman A.M. 1997. Analisis Data Kualitatif. Universitas Indonesia Press.

Pusat Kurikulum, Badan Penelitian dan Pengembangan, Kegiatan Belajar Mengajar yang efektif , Jakarta: Rineka Cipta, 2006.

Sudjana, Nana. 2001. Penilaian Hasil Proses Belajar Mengajar. Bandung:Tarsito

Sudjana, Nana. 1998. Dasar-dasar Proses Belajar Mengajar. Bandung: Sinar Baru Algensindo. 